\title{
Modelling and optimization of proximate and anti- nutritional composition of breakfast cereals produced from blends of millet, mungbean and tigernut flour using response surface methodology
}

\author{
Eweama, A.U.*, Nwosu, J.N., Owuamanam, C.I., Obeleagu, S.O \\ Department of Food Science and Technology, Federal University of Technology Owerri, Imo state, Nigeria
}

\begin{abstract}
Three components augmented simplex centroid design of Response Surface Methodology (RSM) was applied to model and optimized the proximate and anti-nutritional composition of breakfast cereals produced from blends of millet, mungbean and tigernut flour. Blends were variously pre-treated, millet by soaking, mungbean by malting and tigernut by defatting. The experimental values were obtained and subjected to regression analysis to generate regression equations. The linear, binary and ternary effects of the blends were generated and graphically expressed on 3-D surface plots. The developed models were validated at $\mathbf{p}<\mathbf{0 . 0 5}$. Furthermore, optimization of outcomes was selected at desirability of $\mathbf{0 . 4 6 4}$. The result showed that experimental values for protein; $11.83 \%, 21.59 \%, 8.56 \%$ respectively for millet, mungbean and tigernut. The regressed values showed good correlation with the predicted values. The optimum blends selected at a desirability of 0.464 were $0.00 \mathrm{~g}$ millet, 70.36g mungbean, and $29.63 \mathrm{~g}$ tigernut will give the best breakfast meal. Confirmatory runs were done to ascertain $95 \%$ confidence of the optimum values. The three component argumented simplex centroid experimental design of response surface methodology was adequate in modelling and optimization of the parameters: moisture, ash, crude fiber, fat protein, carbohydrate, oxalate, phytate and tannin.
\end{abstract}

Keywords: Proximate composition, Anti-nutritional composition, Breakfast cereals, Simplex centroid design

\section{INTRODUCTION}

$\mathrm{N}$ igeria is a country with an abundance of food that can be used for proper nutrition, as well as for the formulation of breakfast cereals. Despite the abundance of foods, there is malnutrition. Malnutrition does not only persist but remains widespread in many developing countries. Protein Energy Malnutrition (PEM) and micronutrient deficiencies among infants and children have been shown to be directly and individual associated with more than $50 \%$ of all childhood morbidity and mortality in the developing world (Standing Committee on Nutrition, 2004). The WHO and UNICEF are very much concerned about this trend. This is due mainly to lack of adequate and good quality formulated foods, poor processing methods and the presence of anti-nutritional factors such as tannin, oxalate, and phytate (Gee \& Harold, 2004). The amount of cereal grown in Nigeria is high compared to its utilization. This is due to post harvest losses incurred from cereals, thus there is need to diversify the use of cereals into producing some products which can be made available all year. Cereals are most important part of human diet because they provide energy and nutrient intake of humans (Jones, 2003).

Breakfast cereals are foods made by swelling, grinding, rolling or flaking of any cereal (Sharma \& Caralli, 2004). Breakfast cereals are rapidly gaining acceptance in most developing countries and gradually replacing most traditional diets that are used as breakfast meals due to convenience, nutritional values, improved income and status symbol and job demands especially among urban dwellers, (Abbey \& Ibeh, 1988).According to Jones (2003) breakfast cereals facilitate independence because of their ease of preparation which means that children and adolescents can be responsible for their own breakfast or snacks. Such foods may need to be reconstituted, preheated in a vessel or allowed to thaw if frozen before consumption, or they may be eaten directly without further treatment (Okaka, 2005). Their consumption has also been extended to non-breakfast hours and often serve as in-between meals. A study has clearly shown that $42 \%$ of 10 -year-olds and $35 \%$ of young adults consumed cereal at non-breakfast period (Haines et al., 1996); it could be taken dry as snack food, with or without cold or hot milk, based on their location, availability of resources and habits.

The growing third world population requires more protein and nutritious food to combat malnutrition. The cheapest source of protein and other nutrients could be derived from underutilized plant materials that are in abundance in the developing countries. It is evident that plant nutrients are the best alternative to proteins derived from animal source (Sharma \& Caralli, 2004). The utilization of cereals and legumes-based foods by the human race offers them an essential place in global nutrition which plays a vital part in the conventional food practice of many provinces all over the world. Underutilized crops make a significant position in human nutrition particularly in the dietary pattern of low economic population from budding countries are said to be the best combination for delivering good nutrients 
(Anderson et al., 1999 \& Messina, 1999). Underutilized cereals and legumes provide positive health responses when they are properly examples positioned in the daily diet (Kushi et al., 1999). Kaur et al. (2014) revealed associations between the utilization of legumes and declining prevalence of numerous diseases for example: aging, cancer, diabetes and cardiovascular diseases. Jacobs (1998) reported that cereals and its products show beneficial effects in reducing the risk of cancer. The relationship between cereal intake and different type of cancer has been evidenced by several researchers (Anderson et al., 1999)

Millet are rich in resistant starch, soluble and insoluble dietary fibers, minerals and antioxidants (Ragee $e t$ al., 2006). It contains about $92.5 \%$ dry matter, $2.1 \%$ ash, $2.8 \%$ crude fiber. $7.8 \%$ crude fat, $13.6 \%$ crude protein, $63.2 \%$ starch, (Ali \& EI-Tinay,2003). Thus, the availability of these nutrients in millet makes it suitable for large scale utilization in the production of food products such as: breakfast foods. Mung bean (Vigna radiata) is still underutilized as food due to its tough texture, long cooking time and lack of knowledge on its nutritional composition. Its consumption is occasional. Mung bean can provide significant amounts of protein (240 $\mathrm{g} / \mathrm{kg})$, carbohydrate $(630 \mathrm{~g} / \mathrm{kg})$ and a range of micronutrients in diets (Anwar et al., 2007). Mungbean protein and carbohydrates are easily digested and create less flatulence than those derived from other legumes. Tigernut (Cyperus escullentum) tuber is an underutilized crop, which contain $38 \% \mathrm{Kcal}(1635 \mathrm{~kg}$ ), $7.15 \%$ protein, $35 \%$ fat (oil), $46 \%$ starch, $6 \%$ fibre. It is also rich in mineral especially phosphorus and potassium and vitamin E and C (Belewu \& Abodunrin, 2008, Oladele \& Aina 2007).

Apart from supplementation and processes that reduces or removes antinutrient substances in breakfast cereals, there is need to investigate the nutrient composition as well. Knowledge of food composition (Greenfield \& Southgate, 2003) and anti-nutritional composition of food is important for nutrition planners and also understanding their behavior during preparation. Response surface methodology (RSM) is a statistical technique for the design, empirical modelling and optimization of processes, where the responses of interest are influenced by several process variables (Freeny, Box, \& Draper,1988; Gunst et al., 1996).Response surface methodology (RSM) was applied to investigate the relationships between different independent and response variables while minimizing the number of experiments and usage of resources. Hence, the objective of this study was to model and optimize the proximate and anti-nutritional composition of breakfast cereals produced from blends of millet, mungbean and tigernut flour using response surface methodology.

\section{MATERIALS AND METHODS}

\subsection{Materials}

Millet (Green pearl millet) and tigernut were purchased from Relief market, Imo state, Nigeria while mungbean (Green) was supplied from Kingsway Market Apapa Lagos state, Nigeria. The millet, tigernut and mungbean were identified in Crop Science Technology Department, FUTO. The chemicals used were of analytical grade; and both the equipment were obtained from the Department of Food Science and Technology, Federal University of Technology Owerri, Imo State; Polytechnic, Umuagwo-Ohji; University of Ilorin, University of Jos Plateou State, Nigeria and National Root Research Institute Umudike, Umuahia Abia State Nigeria. Proximate composition analysis was carried out at Nigerian Store Product Research Institute Port Harcourt. Anti-nutritional composition analysis was carried out at Nigeria and National Root Research Institute Umudike, Umuahia.

\subsection{Methods}

\subsubsection{Production of Millet flour}

The method of Jideani (2005) was adopted for the production of millet flour. Two $(2 \mathrm{~kg})$ kilograms of millet was cleaned, sorted to remove dirt and any form of impurity. The cleaned and washed millet were soaked for $12 \mathrm{~h}$ at ambient temperature and rinsed thoroughly with distilled water. The millet was dried in an oven (DHG-9023A, Zenith Laboratory China) at $65^{\circ} \mathrm{C}$ for $6 \mathrm{~h}$. It was further milled into flour with attrition mill and sieved ( $300 \mathrm{~mm}$ sieve) to obtain fine flour. The flour sample obtained was packaged in an air tight container and kept for further analysis. The flow chart for millet four production is shown in Figure 1.

\subsubsection{Production of Mungbean flour}

Sprouted mungbean flour was processed following the method described by Mubarak (2005) with slight modification. Two kilograms $(2 \mathrm{~kg})$ of mungbean seed was cleaned, sorted and washed with distilled water, soaked by submerging the sample in distilled water at ambient temperature in a transparent container for $12 \mathrm{~h}$ at ambient temperature. Thereafter, the seeds were spread out on a sterile jute bag and covered with a muslin cloth and kept at an ambient temperature. The sample was allowed to germinate (sprout for $24 \mathrm{~h}$ ), during this period, distilled water was sprinkled on the white muslin cloth every $6 \mathrm{~h}$. After $24 \mathrm{~h}$, the sprouted seeds were cleaned and dried in an air oven (DHG9023A, Zenith Laboratory China) at $60^{\circ} \mathrm{C}$, for $9 \mathrm{~h}$, and milled to obtain malted mungbean flour, packaged and stored in an air tight container for further analysis.

\subsubsection{Production of Tiger nut flour}

Two kilograms $(2 \mathrm{~kg}$ ) of fresh tigernut was cleaned, sorted, and washed thoroughly to remove any form of impurity. Cleaned tigernuts were milled into paste, homogenized in boiled water $\left(100^{\circ} \mathrm{C}\right)$ and poured into a muslin cloth and squeezed to express the milk. The tigernut spent mash was dried $\left(60^{\circ} \mathrm{C}\right.$ for $\left.8 \mathrm{~h}\right)$ in an oven (DHG-9023A, Zenith Laboratory China), packaged in air tight container for further analysis (Adejuyitan, 2011). 


\subsubsection{Production of breakfast cereals}

The method of Okafor \& Usman (2014) was adopted for the production of breakfast cereals. One hundred grams $(100 \mathrm{~g})$ each of millet flour, sprouted mungbean flour and tigernut flour were blended. Two grams $(2 \mathrm{~g})$ of sugar, $0.5 \mathrm{~g}$ of salt, $5 \mathrm{ml}$ of vanilla flavor and $20 \mathrm{ml}$ of distil water were added. They were mixed together and toasted at $150^{\circ} \mathrm{C}$ for 10 min in an oven. Thereafter, it was cooled, milled and packaged (Figure 1)

\subsection{Determination of Proximate Composition}

The proximate (moisture, ash, fiber, fat, and protein) content of the blends were determined following the standard methods of AOAC (2015). The carbohydrate content of the samples was calculated by simple difference method as reported by Onwuka (2018).

\subsubsection{Moisture Content}

Two grams ( $2 \mathrm{~g}$ ) of each of the sample was weighed into dried weighed crucible. The samples were put into a moisture extraction oven at $105^{\circ} \mathrm{C}$ and heated for $3 \mathrm{~h}$. The dried samples were put into desiccator, allowed to cool and reweighed. The process was repeated until a constant weight was obtained. The difference in weight was calculated as a percentage of the original sample.

Percentage moisture $=\frac{W_{2}-W_{2}}{W_{2}-W_{3}} \times \frac{100}{1}$

\section{Where}

$\mathrm{W}_{1}=$ Initial weight of empty dish, $\mathrm{W}_{2}=$ Weight of dish + undried sample

$\mathrm{W}_{3}=$ Weight of dish + dried sample

\subsubsection{Ash Content}

Two grams ( $2 \mathrm{~g})$ of each of the samples were weighted into crucibles and heated in a moisture extraction oven for $3 \mathrm{~h}$ at $100^{\circ} \mathrm{C}$ before being transferred into a muffle furnace at $550^{\circ} \mathrm{C}$ until it turned ash/ white and free of carbon. The sample was then removed from the furnace, cooled in a desiccator to a room temperature and reweighed immediately. The weight of the residual ash was then calculated as

Percentage ash content $=\frac{\text { Weight of Ash }}{\text { Weight of original sample }} \times \frac{100}{1}(2)$

\subsubsection{Crude Protein}

Two grams ( $2 \mathrm{~g})$ of each of the samples was mixed with $10 \mathrm{ml}$ of concentrated $\mathrm{H}_{2} \mathrm{SO}_{4}$ in a test tube. One tablet of selenium catalyst was added to the test tube and mixture heated inside a fume cupboard. The digest was transferred into distilled water. A $10 \mathrm{ml}$ portion of the digest, mixed with equal volume of $45 \% \mathrm{NaOH}$ solution was poured into a kjeldahl distillation apparatus. The mixture was distilled and the distillate collected into a flask containing $4 \%$ boric acid solution and 3 drops of methyl red indicator. A total of $50 \mathrm{ml}$ distillate was collected and titrated against sodium hydroxide.
Triplicate values were measured and the mean obtained. The Nitrogen content was calculated and multiplied with 6.25 to obtain the crude protein content. This is given as percentage Nitrogen $=\frac{(100 \times N \times V F) T}{100 \times V_{a}}$

Where

$\mathrm{N}=$ Normality of the titrate $(0.1 \mathrm{~N}), \mathrm{VF}=$ Total volume of the digest $=100 \mathrm{ml}, \mathrm{T}=$ Titre Value

$\mathrm{Va}=$ Aliquot Volume distilled

\subsubsection{Fat Content}

Two grams ( $2 \mathrm{~g})$ of the sample was loosely wrapped with a filter paper and put into the thimble which was fitted to a clean round bottom flask, which has been cleaned, dried and weighed. The flask contained $120 \mathrm{ml}$ of petroleum ether. Thesample was heated with a heating mantle and allowed to reflux for $5 \mathrm{~h}$. The heating was then stopped and the thimbles with the spent samples kept and later weighed. The difference in weight was calculated as mass of fat and is expressed in percentage of the sample.

The percentage oil content is percentage fat $=\frac{W_{2}-W_{1}}{W_{3}} \times \frac{100}{1}$

\section{Where}

$\mathrm{W}_{1}=$ weight of the empty extraction flask, $\mathrm{W}_{2}=$ weight of the flask and oil extracted

$\mathrm{W}_{3}=$ weight of the sample

\subsubsection{Crude Fiber}

Two grams $(2 \mathrm{~g})$ of the sample and $1 \mathrm{~g}$ asbestos were put into $200 \mathrm{ml}$ of $1.25 \%$ of $\mathrm{H}_{2} \mathrm{SO}_{4}$ and boiled for $30 \mathrm{~min}$. The solution was poured into Buchner funnel equipped with muslin cloth and secured with elastic band. This was allowed to filter and the residue was then put into $200 \mathrm{ml}$ boiled $\mathrm{NaOH}$ and boiling continued for $30 \mathrm{~min}$, then transferred to the Buchner funnel and filtered. It was then washed twice with alcohol, the material obtained washed thrice with petroleum ether. The residue obtained was put in a clean dry crucible and dried in the moisture extraction oven to a constant weight. The dried crucible was removed, cooled and weighed. The difference in weight (i.e. loss in ignition) was recorded as crude fibre and expressed as

Percentage Crude Fibre $=\frac{W_{1}-W_{2}}{W_{t}} \times \frac{100}{1}$

Where

$\mathrm{W}_{1}=$ weight of sample before incineration, $\mathrm{W}_{2}=$ weight of sample after incineration

$\mathrm{W}_{\mathrm{t}}=$ weight of original sample 


\subsubsection{Carbohydrate}

The carbohydrate is calculated as weight by difference between 100 and the summation of other proximate parameters as Nitrogen free Extract (NFE) percentage carbohydrate $(\mathrm{NFE})=100-(M+P+F 1+A+F 2)$ (6)

\section{Where:}

$\mathrm{M}=$ Moisture, $\mathrm{P}=$ Protein, $\mathrm{F}_{1}=$ Fat, $\mathrm{A}=$ ash, $\mathrm{F}_{2}=$ Crude fiber

\subsection{Determination of Anti-nutritional Factors}

\subsubsection{Oxalate}

The titration method of (AOAC, 2015) was followed in the determination of oxalate. Two grams of sample was suspended in a mixture of $190 \mathrm{ml}$ of distilled water in a 250 $\mathrm{ml}$ volumetric flask. Ten $(10 \mathrm{ml})$ of $6 \mathrm{M} \mathrm{HC1}$ and the suspension was heated for $1 \mathrm{~h}$ at $100^{\circ} \mathrm{C}$ in a water bath. The mixture was cooled and made up to $250 \mathrm{ml}$ mark with distilled water before filtration. Duplicate portion of $125 \mathrm{ml}$ of the filtrate was measured into $250 \mathrm{ml}$ beakers. Each extract was made alkaline with concentrated sodium hydroxide then made acid by drop wise addition (4 drops) of acetic acid until the test solution is changed from salmon pink to faint yellow $(\mathrm{pH}$ 4-4.5) (methyl red indicator used). Each portion was heated at $90^{\circ} \mathrm{C}$ to remove precipitate containing ferrous ions. The filtrate was heated again to $90^{\circ} \mathrm{C}$ on a hot water bath and 10 $\mathrm{ml}$ of 5\% calcium chloride solution added while being stirred constantly. After heating, it was centrifuged at full speed (2500 rpm) for $5 \mathrm{~min}$. The supernatant was decanted and the precipitate completely dissolved in $10 \mathrm{ml}$ of $20 \%(\mathrm{v} / \mathrm{v}) \mathrm{H}_{2} \mathrm{SO}_{4}$ solution and the total filtrate resulting from $2 \mathrm{~g}$ of the sample was made up to $300 \mathrm{ml}$.

Permaganate titration: Aliquot of $125 \mathrm{ml}$ of the filtrate was heated until near boiling and then titrated against $0.05 \mathrm{M}$ $\mathrm{KMNO}_{4}$ solution to a faint pink color which persisted for 30 sec. Oxalic acid content was calculated using the formula,

$\%$ Oxalic acid $=\frac{T x\left(V_{m e}\right)\left(D_{f}\right) \times 10^{5}}{M E \times M_{f}}$

Where: $\mathrm{T}=$ Titre of $\mathrm{KMNO}_{4}(\mathrm{ml}), \mathrm{V}_{\mathrm{me}}=$ volume - mass equivalent $\left(1 \mathrm{ml}\right.$ of $0.05 \mathrm{M} \mathrm{MNO}_{4}$ solution is equivalent to $0.0022 \mathrm{~g}$ anhydrous oxalic acid), $\mathrm{Df}=$ the dilution factor (i.e. $300 \mathrm{ml}) 125 \mathrm{ml}, \mathrm{ME}=$ the molar equivalent of $\mathrm{KMNO}_{4}$ in oxalic acid $\left(\mathrm{KMNO}_{4}\right.$ redox reaction is 5$), \mathrm{Mf}=$ the mass of the sample used.

\subsubsection{Phytate or Phytic Acid}

The phytate determination was carried out as described by A.O.A.C (2015). Two grams of each of the samples was placed in a flask into which $100 \mathrm{ml}$ of $1.2 \mathrm{HC} 1$ and $10 \% \mathrm{Na}_{2} \mathrm{SO}_{4}$ were added. The flask was stoppered and shaken for $2 \mathrm{~h}$ on a mechanical shaker. The extract was vacuum filtered through No. 4 Whatman paper. $10.0 \mathrm{ml}$ of the filtrate was pipetted into a $50 \mathrm{ml}$ centrifuge tube. Ten $(10 \mathrm{ml})$ deionized water was added, followed by $12 \mathrm{ml}$ of $\mathrm{FeCl}$ solution $\left(2.0 \mathrm{~g} \mathrm{FeCl}_{3} \cdot 6 \mathrm{H}_{2} \mathrm{O}\right)+16.3 \mathrm{ml}$ cone. $\mathrm{HC} 1$ per litre). The mixture was stirred, heated for $75 \mathrm{~min}$ in boiling water and cooled, covered for $1.0 \mathrm{~h}$ at room temperature. The tube was centrifuged at $1000 \mathrm{Xg}$ for $15 \mathrm{~min}$. The supernatant was decanted and discarded and the pellet was thoroughly washed thrice with a solution of $0.6 \% \mathrm{HC} 1$ and $2.5 \% \mathrm{NaSO}_{4}$. After each wash, the mixture was centrifuged at $1000 \mathrm{Xg}$ for $10 \mathrm{~min}$ and the supernatant discarded. $10 \mathrm{ml}$ concentrated $\mathrm{HNO}_{3}$ was added to the resulting pellet and transferred quantitatively to a $400 \mathrm{ml}$ beaker with several small portions of deionized water. Four drops of concentrated $\mathrm{H}_{2} \mathrm{SO}_{4}$ was added and content heated approximately $30 \mathrm{~min}$ in a hot plate until only the $\mathrm{H}_{2} \mathrm{SO}_{4}$ is left. Approximately $5 \mathrm{ml}$ of $30 \% \mathrm{H}_{2} \mathrm{O}_{2}$ was added and the mixture returned to the hot plate at a low heat until bubbling ceases. The residue was dissolved in $15 \mathrm{ml} 3 \mathrm{~N} \mathrm{HC1}$ and heated for $15 \mathrm{~min}$. The resulting solution was made up of $100.0 \mathrm{ml}$ volume diluted 15 and then analyzed for iron using Franson et al. (1975) procedure.

\subsubsection{Tannin}

The Folin-Denis colorimetric method as described by Kirk \& Sawyer (1991) was used for the determination of tannin content in the samples as follows: $5 \mathrm{~g}$ of the sample was dispersed in $50 \mathrm{ml}$ of distilled water and agitated. The mixture was allowed to stand for $30 \mathrm{~min}$ at room temperature and shaken every $5 \mathrm{~min}$. After $30 \mathrm{~min}$ it was centrifuged at $1000 \mathrm{xg}$ for $30 \mathrm{~min}$ and the extract obtained. The extract $(2 \mathrm{ml})$ was taken into a $50 \mathrm{ml}$ volumetric flask. Similarly, $2 \mathrm{ml}$ standard tannin solution (tannic acid) and $2 \mathrm{ml}$ of distilled water was put in separate $50 \mathrm{ml}$ volumetric flask to serve as standard. The reagent $(1.0 \mathrm{ml}$ of Folin-Denis) was added to each of the flasks, followed by addition of $2.5 \mathrm{ml}$ of saturated sodium carbonate solution. The content of each flask was made up to $50 \mathrm{ml}$ with distilled water and allowed to incubate for $90 \mathrm{~min}$ at room temperature. Their respective absorbance was measured in a spectrophotometer (SP-1901, Shnaghai Spectrum Instrument Co., China) at $250 \mathrm{~nm}$ using reagent blank to calibrate the instrument at zero. The tannin content was calculated using the formula,

$\%$ Tannin $=\mathrm{An} / \mathrm{W} \times \mathrm{C} / \mathrm{V}_{\mathrm{a}} \times \mathrm{Vf} \times 100 / 1$

Where:

$\mathrm{An}=$ Absorbance of test sample, AS = Absorbance of standard solution, $\mathrm{C}=$ Concentration of standard solution, $\mathrm{W}$ $=$ Weight of sample used, $\mathrm{Vf}=$ Total volume of extract, $\mathrm{V}_{\mathrm{a}}$ $=$ Volume of extract analyzed.

\subsection{Experimental Design and Statistical Analysis}

The three simplex centroid experimental design of response surface methodology (RSM) as described by Scheffe (1963) was used to develop predictive models and to investigate the linear, binary and ternary blends of process parameters (millet flour, mungbean flour, tigernut flour) on the proximate and anti-nutritional composition of breakfast cereals in which 14 runs/design points were conducted. Four runs were replicated to estimate the internal error within the design as shown in 
Table 1. Analysis of variance (ANOVA) was carried out on data from proximate and anti-nutritional composition of flours (millet, mungbean and tiger nut). A p-value $(\mathrm{p}<0.05)$ was considered significant as shown in Table 2. The generation of response surface plots and statistical analysis were performed using Design-Expert (Version 12.0.6.2, State-Ease, Inc. Minneapolis, 2015) software. ANOVA was also performed using this software and model significance $(\mathrm{p}<0.05)$, lack of fit and adjusted regression coefficients $\left(\mathrm{R}_{\text {adj }}{ }^{2}\right)$ which indicate the model fitness were determined from the analysis. Special cubic model was adopted as stated below:

$$
\begin{aligned}
y=\sum_{i=1}^{q} \beta_{i} x_{i}+\sum_{i \neq j}^{q} \beta_{i j} x_{i} x_{j} \\
+\sum_{i \neq j \neq k}^{q} \beta_{i j k} x_{i} x_{j} x_{k} \\
+\varepsilon_{i j k}
\end{aligned}
$$

Where, $\beta_{i}$ are the main effects, $\beta_{i j}$ are the binary joint effects between the $i^{t h}$ and $j^{\text {th }}$ components, $\beta_{i j k}$ are the ternary joint effects between the $i^{t h}, j^{t h}$ and $k^{\text {th }}$ components.Y is the predicted response, $\mathrm{q}$ is the number of process parameters $(\mathrm{q}=$ 3 in this study), $\varepsilon_{i j k}$ is error involved in estimating the components from the experimental data. The special cubic model equation proposed for each response of $Y$ can also be written as

$$
\begin{gathered}
Y=\beta_{1} x_{1}+\beta_{2} x_{2}+\beta_{3} x_{3}+\beta_{12} x_{1} x_{2}+\beta_{13} x_{1} x_{3}+\beta_{23} x_{2} x_{3} \\
+\beta_{123} x_{1} x_{2} x_{3}
\end{gathered}
$$

where $\mathrm{Y}$ is the predicted response, $\beta$ 's are the parameter estimates for each linear and cross product term for the prediction model, $x_{1}, x_{2}, x_{3}, x_{1} x_{2}, x_{1} x_{3}, x_{2} x_{3}$ and $x_{1} x_{2} x_{3}$ are the linear terms of millet, mungbean and tiger nut and the cross product terms of millet $\mathrm{x}$ mungbean, millet $\mathrm{x}$ tiger nut, mungbean $\mathrm{x}$ tiger nut, and millet $\mathrm{x}$ mungbean $\mathrm{x}$ tiger nut flours respectively. The model chosen was based on a significant model $(\mathrm{p}<0.05)$, insignificant lack of fit and highest $\mathrm{R}^{2}$ as recommended by Cornell (1986). The criteria for the responses were stated and numerically optimized (Myers, Montgomery,\& Anderson-Cook, 2009) as shown in Table 3\& 4.The model was validated by plotting the actual values or experimental values against the predicted values (Vining, Cornell, \&Myers, 1993) as shown in Figure 2

\section{RESULTS AND DISCUSSION}

3.1 Proximate composition of breakfast cereals produced from blends of millet, mungbean and tigernut flour

\subsubsection{Moisture content}

The moisture content of the breakfast cereals is shown in Table1. The values ranged from $5.57 \%$ to $7.38 \%$. The variation in moisture content was due to the processing methods of individual flour. This was subjected to statistical analysis as indicated in Table 2. Statistically, significant $(p<0.05)$ linear effects of millet (6.37), mungbean (7.43) and tigernut (5.85) were observed in moisture content as shown in Table 2. This is in line with the findings of Ghavidel \& Davoodi (2014). Moisture content of foods is influenced by type, variety and storage condition (Eshun, 2012). Therefore, the storage of this product would require careful reduction of the moisture content by drying. A very high degree of precision and a good deal of the reliability of the experiment was indicated by a low value of the coefficient of variation (5.78\%) as shown in Table 2. The $\mathrm{R}^{2}(0.6783)$ and nonsignificant $(\mathrm{p}>0.05)$ lack of fit showed the adequacy of the model. The model was significant $(p=0.0020)$ and it explained $61.98 \%$ of all variance in the data. The remaining $38.02 \%$ are attributed to factors not included in the model. The 3-D surface plot for the moisture content is shown in Figure 2. The model was validated by plotting the graph of the predicted values against the actual values as shown in Figure 11. Good correlation existed between the predicted values and actual values. Hence, the significant $(\mathrm{p}<0.05)$ model equation for the moisture content was

Moisture content $=6.37 x_{1}+7.43 x_{2}+5.85 x_{3}$

\subsubsection{Ash content}

Table 1 showed the ash content of the breakfast cereals. The values ranged from $1.13 \%$ to $3.33 \%$. The difference in ash content between the samples was probably due to processing technique, heat treatment, and difference in cultivar (Mbaeyi-Nwaoha \& Uchendu, 2015; Mateos-Aparicio et al.,2010). Ash content is an indication of mineral content of a food. However, statistically as shown in Table 2, there was highly significant $(\mathrm{p}<0.0001)$ linear effects of millet $\left(1.12 x_{1}\right)$, mungbean $\left(3.33 x_{2}\right)$ and tigernut $\left(1.77 x_{3}\right)$ which resulted in high ash content of the breakfast cereal. Also, significant $(\mathrm{p}<0.05)$ binary effects of millet and mungbean flours $\left(-0.71 x_{1} x_{2}\right)$, millet and tigernut flours $\left(-0.74 x_{1} x_{3}\right)$ produced low ash content. The highest increase in the ash content was observed in ternary effects of millet, mungbean and tigernut flours $\left(5.12 x_{1} x_{2} x_{3}\right)$. The increase in ash is indicative of high mineral content of the breakfast cereals from blends of millet, mungbean and tigernut flours. The low ash content observed may be as a result of the sprouting of mungbean.Mbaeyi \& Onweluzo, (2010) reported that sprouting decreased ash content. The treatments (sprouting) aided the removal of the vegetative part of the seeds during milling leading to losses in dry matters and leaching of the nutrients.Furthermore, low value of the coefficient of variation $(1.82 \%)$ indicated higher precision and reliability of the experiment. The $\mathrm{R}^{2}(0.9986)$ and non-significant $(\mathrm{p}>0.05)$ lack of fit showed the adequacy of the model. The model was highly significant $(\mathrm{p}<0.0001)$. It explained $99.74 \%$ of all variance in the data while the remaining $0.26 \%$ was caused by factors not included in the model. The plot of predicted values and actual values showed the validity of the model as indicated in Figure 12. This showed that the predicted and actual values were closely related. The 3-D surface plot for the ash content is shown in Figure 3. The significant $(\mathrm{p}<0.05)$ model equation for ash content was: 


$$
\begin{aligned}
\text { Ash content }= & 1.12 x_{1}+3.33 x_{2}+1.77 x_{3}-0.71 x_{1} x_{2} \\
& -0.74 x_{1} x_{3}+5.12 x_{1} x_{2} x_{3}
\end{aligned}
$$

\subsubsection{Crude fiber}

Crude fiber ranged from $4.72 \%$ to $24.63 \%$ as shown in Table 1. Crude fiber is a measure of the quantity of indigestible cellulose, pentosans, lignin and other components of this type in present foods (Arawande \& Borokini, 2010). Table 2 showed that linear effects of millet $\left(5.40 x_{1}\right)$, mungbean $\left(6.38 x_{2}\right)$ and tigernut flour $\left(24.46 x_{3}\right)$ were highly significant $(\mathrm{p}<0.0001)$. This produced high crude fiber. Oladunmoye et al., (2010) reported that food rich in crude fiber helps in the treatment of heart diseases, colon cancer, diabetes etc. Furthermore, Table 2 indicated that a low value of the coefficient of variation (17.08\%) showed a very high degree of precision and a good deal of the reliability of the experiment. The $R^{2}(0.9549)$ and non-significant $(p>0.05)$ lack of fit showed the adequacy of the model. The model was highly significant $(\mathrm{p}<0.0001)$. The model explained $92.67 \%$ of all variance in the data. The predicted values were plotted against actual values as shown in Figure 13. A close relationship between predicted and actual values was observed which showed the validity of the model. The 3-D surface plot for the ash content is shown in Figure 4.Therefore, the significant $(\mathrm{p}<0.05)$ model equation for the crude fiber was:

Crude fiber $=5.40 x_{1}+6.38 x_{2}+24.46 x_{3}$

\subsubsection{Fat content}

Table 1 indicated that the fat content ranged from $1.77 \%$ to $16.21 \%$. The differences in fat content may be due to location and varietal differences (Moss, Gore, \& Murray, 1987). Statistically, high fat content of the breakfast cereals was observed in the highly significant $(p<0.0001)$ linear effects of millet $\left(5.96 x_{1}\right)$, mungbean $\left(1.56 x_{2}\right)$ and tigernut flour $\left(15.92 x_{3}\right)$ while the significant $(\mathrm{p}<0.05)$ binary effects of millet and tigernut flours $\left(-20.93 x_{1} x_{3}\right)$ produced low fat content as shown in Table 2. Aiyesanmi \& Oguntokun (1996) revealed that diets with high fat content contribute significantly to the energy requirement for humans. High fat flours are also good for flavour enhancers and useful in improving palatability of foods in which it is incorporated. This implies that this product would be energy dense foods suitable for people such as sportsmen that require lot of energy to work. Also, a very high degree of precision and a good deal of the reliability of the experiment was indicated by a low value of the coefficient of variation $(22.77 \%)$ as shown in Table 2. The $R^{2}(0.9254)$ and non-significant ( $\left.p>0.05\right)$ lack of fit showed the adequacy of the model. The model was significant $(p=0.0003)$ and it explained $87.88 \%$ of all variance in the data. The remaining $12.12 \%$ are attributed to factors not included in the model. The 3-D surface plot for the fat content is shown in Figure 5. The model was validated by plotting the graph of the predicted values against the actual values as shown in Figure 14. This showed that the predicted values and actual values were closely related. Hence, the significant $(\mathrm{p}<0.05)$ model equation for the fat content was:

$$
\begin{aligned}
\text { Fat content }= & 5.96 x_{1}+1.56 x_{2}+15.92 x_{3} \\
& -20.93 x_{1} x_{3}
\end{aligned}
$$

\subsubsection{Protein content}

The protein content of breakfast cereals ranged from $8.56 \%$ to $21.59 \%$ as observed in Table 1 . The protein content differences can be attributed to the geographical location. Since soils with high nitrogen levels can influence protein levels (Brown, 1991). Table 2 showed that highly significant $(\mathrm{p}<0.0001)$ linear effects of millet $\left(11.30 x_{1}\right)$, mungbean $\left(22.06 x_{2}\right)$ and tigernut $\left(9.11 x_{3}\right)$ produced high protein content of the breakfast food product. The high protein content of the products may be attributed to the presence of mungbean flour component used in the product. Mungbean has been reported to contain 25\% protein (Dongyan et al., 2014). Temple \& Bassa (1991) reported that addition of legume to cereals improves the level of protein. The protein content of the flours in this product suggests that they may be useful in food formulation systems. Protein is needed for tissue replacement, deposition of lean body mass and growth. Moreover, a very high degree of precision and a good deal of the reliability of the experiment was indicated by a low value of the coefficient of variation (8.74\%) as shown in Table 2. The $\mathrm{R}^{2}(0.9344)$ and non-significant $(\mathrm{p}>0.05)$ lack of fit showed the adequacy of the model. The model was highly significant $(\mathrm{p}<0.0001)$ and it explained $92.25 \%$ of all variance in the data. The remaining $7.75 \%$ are attributed to factors not included in the model. The 3-D surface plot for the moisture content is shown in Figure 6. The model was validated by plotting the graph of the predicted values against the actual values as shown in Figure 15. Good correlation existed between the predicted values and actual values as observed from the plot. Thus, the significant $(\mathrm{p}<0.05)$ model equation for the protein content was:

$$
\begin{aligned}
\text { Protein content } & =11.30 x_{1}+22.06 x_{2} \\
& +9.11 x_{3}
\end{aligned}
$$

\subsubsection{Carbohydrate}

Table 1 showed that the carbohydrate content ranged from $43.26 \%$ to $70.3 \%$. Carbohydrates are good sources of energy and that a high concentration of it isdesirable in breakfast meals and weaning formulas. Highly significant $(\mathrm{p}<0.0001)$ linear effects of millet $\left(70.06 x_{1}\right)$, mungbean $\left(59.14 x_{2}\right)$ and tigernut $\left(43.43 x_{3}\right)$ produced high carbohydrate while the significant $(\mathrm{p}<0.05)$ binary effects of mungbean and tigernut flours $\left(20.68 x_{2} x_{3}\right)$ produced the highest carbohydrate as indicated in Table 2. The high carbohydrate content of this product suggested that it could be used in managing proteinenergy malnutrition since there is enough quantity of carbohydrate to derive energy from in order to spare protein so that protein can be used for its primary function of building the body and repairing worm-out tissues rather an as a source of energy (Butt \& Batool, 2010). Awolu et al., (2015) 
reported that carbohydrates are good sources of energy and that a high concentration of it is desirable in breakfast meals and weaning formulas. A low value of the coefficient of variation $(2.08 \%)$ showed a very high degree of precision and a good deal of the reliability of the experiment. The $R^{2}$ (0.9864) and non-significant ( $\mathrm{p}>0.05)$ lack of fit showed the adequacy of the model. The model was highly significant $(\mathrm{p}<0.0001)$. The model explained $97.78 \%$ of all variance in the data. The predicted values were plotted against actual values as shown in Figure 7. The plot indicated that the predicted and actual values were closely related. This showed the validity of the model. The 3-D surface plot for the ash content is shown in Figure 16.

Hence, the significant $(\mathrm{p}<0.05)$ model equation for the carbohydrate was:

$$
\begin{aligned}
\text { Carbohdrate }= & 70.06 x_{1}+59.14 x_{2}+43.43 x_{3} \\
& +20.68 x_{2} x_{3}
\end{aligned}
$$

3.2Anti-nutritional composition of breakfast cereals produced from blends of millet, mungbean and tigernut flour

\subsubsection{Oxalate}

Oxalate content ranged from 0.27 to $2.05 \mathrm{mg} / 100 \mathrm{~g}$ as shown in Table 1. Oxalate is an abundant metabolic end product in plants. The variation in the oxalate content of foods is mainly determined by the plant family (Siener et al., 2006). Statistically, significant $(\mathrm{p}<0.05)$ linear effects of millet $\left(1.83 x_{1}\right)$, mungbean $\left(3.12 x_{2}\right)$ and tigernut $\left(0.89 x_{3}\right)$ produced high oxalate as indicated in Table 2. Franziska (2017) reported that many foods that contained oxalates are delicious and provide many health benefits. Avoiding them is not necessary for most people and may even be detrimental. Most healthy people can consume oxalate rich foods without problems but those with altered gut function may need to limit their intake (Habauzet \& Morand, 2012).Morrison \& Savage (2003) revealed that the consumption of high-oxalate foods is more likely to pose health problems in those who have an unbalanced diet or those with intestinal malfunction. In healthy individuals, the occasional consumption of highoxalate foods as part of a balanced diet does not pose any particular problem. Moreover, low value of the coefficient of variation $(33.07 \%)$ indicated higher precision and reliability of the experiment. The non-significant $(p>0.05)$ lack of fit showed the adequacy of the model. The plot of predicted values and actual values showed the validity of the model (Figure 17). Good correlation was observed between the predicted and actual values. The 3-D surface plot for the oxalate is shown in Figure 8. The significant $(\mathrm{p}<0.05)$ model equation for oxalate was:

$$
\text { Oxalate }=1.83 x_{1}+3.12 x_{2}+0.89 x_{3}
$$

\subsubsection{Phytate}

Phytate ranged from 0.57 to $2.82 \mathrm{mg} / 100 \mathrm{~g}$ as shown in Table 1 . The variation may be caused by many factors, such as genetics, environmental fluctuations, location, irrigation conditions, type of soils, year and fertilizer application that can affect the phytic acid content and phosphorus availability in cereal grains. Phytate are the principal storage form of phosphorus and are particularly abundant in cereals and legumes (Reddy et al.,1982). Table 2 showed that the linear effect of millet $\left(0.27 x_{1}\right)$, mungbean $\left(1.15 x_{2}\right)$ and tigernut $\left(1.43 x_{3}\right)$ produced high phytate. Graf et al. (1987) reported that the most important beneficial functions of phytates were their anti-cancer activity which inhibits the growth of cancer cells. Furthermore, the non-significant $(p>0.05)$ lack of fit showed the adequacy of the model (Table 2). The 3-D surface plot for phytate is indicated in Figure 9. The model was validated by plotting the graph of the predicted values against the actual values as shown in Figure 18. Good correlation existed between the predicted values and actual values. Thus, the significant $(\mathrm{p}<0.05)$ model equation for phytate was:

$$
\begin{array}{r}
\text { Phytate }=027 x_{1}+1.15 x_{2} \\
+1.43 x_{3}
\end{array}
$$

\subsubsection{Tannin}

Table 1 showed that tannin ranged from 0.15 to $1.62 \mathrm{mg} / 100 \mathrm{~g}$. The linear effect of millet $\left(-0.34 x_{1}\right)$, mungbean $\left(-0.55 x_{2}\right)$ and tigernut $\left(-1.78 x_{3}\right)$ significantly $(\mathrm{p}<0.05)$ decreased the tannin while the binary effects of millet and tigernut $\left.\left(4.77 x_{1} x_{3}\right)\right)$, mungbean and tigernut $\left(4.58 x_{2} x_{3}\right)$ significantly $(\mathrm{p}<0.05)$ increased the tannin as observed in Table 2.Consumption of tannin rich foods helped to treat and prevent cancer (Huang et al., 2010). Tannins are water-soluble polyphenols that are present in many plant foods (Chung et al., 1998). Moreover, the $\mathrm{R}^{2}(0.8453)$ and non-significant $(\mathrm{p}>0.05)$ lack of fit showed the adequacy of the model. The model was significant $(p=0.0042)$. The model explained $74.86 \%$ of all variance in the data. The model was validated by plotting the predicted values against actual values as shown in Figure 19. Good correlation was observed between the predicted and actual values. This showed the validity of the model. The 3-D surface plot for tannin is shown in Figure 10. Hence, the significant $(\mathrm{p}<0.05)$ model equation for the tannin was:

$$
\begin{gathered}
\text { Tannin }=-0.34 x_{1}-0.55 x_{2}-1.78 x_{3}+4.77 x_{1} x_{3} \\
+4.58 x_{2} x_{3}
\end{gathered}
$$

\subsection{Optimization}

Numerical optimization of Design Expert" software (Version 12.0.5, Stat-Ease, Inc., Minneapolis, USA) statistical package was adopted to optimize the individual responses to search for a combination of independent variables levels that simultaneously satisfy the target requirement placed on each response and factors. The goal, lower limit, upper limit, lower weight, upper weight and importance were set for each independent variable and response variable as shown in Table 3. Setting the importance at 3 for both the independent and response variables means that no goals are favored over others. The optimum values (Millet flour: $0.000 \mathrm{~g}$, Mungbean flour: $70.37 \mathrm{~g}$, Tigernut flour: $29.62 \mathrm{~g}$, moisture content: 
6.96\%, ash content: $2.92 \%$, crude fiber: $10.02 \%$, fat content: $6.82 \%$, protein content: $18.22 \%$, carbohydrate: $58.80 \%$, oxalate: $0.40 \mathrm{mg} / 100 \mathrm{~g}$, phytate: $0.81 \mathrm{mg} / 100 \mathrm{~g}$ and tannin: $1.04 \mathrm{mg} / 100 \mathrm{~g}$ ) with desirability of 0.464 were selected as shown in Table 4. Numerical optimization ramps view for the variables were indicated in Figure 20. Ramps are graphical representation of optimal solution. Flat ramps indicate uniform desirability (millet flour, mungbean flour and tigernut flour), whereas inclined ramps represent minimum/maximum desired value. Red and blue dots represent factors and responses, respectively. The height of dot corresponds to the level of desirability achieve upon optimization. Desirability bar graph was shown in Figure 21. The bar graph shows how well each variable satisfies the criteria: values near one are good. 3D desirability plot was shown in Figure 22.

\subsection{Confirmation of optimum values (Two-sided Confidence $=$ $95 \%)$}

Table 5 showed the confirmation of optimum values (Twosided Confidence $=95 \%$ ) for modelling and optimization of the proximate and anti-nutritional composition of breakfast cereals produced from blends of millet, mungbean and tigernut flour. Six confirmatory runs were done to ascertain $95 \%$ confidence. It was observed that predicted mean and data mean for each response was close and also, within the range of actual or experimental values. The standard deviation (SD) of the responses (moisture content, protein content, ash content, fat content, crude fibre, carbohydrate, oxalate, phytate and tannin) were low. This showed how close the individual data are from the mean value. Also, the standard error predicted for the responses was small. A small standard error (SE) is an indication that the sample mean is a more accurate reflection of the actual population mean. The standard error is an indication of the reliability of the mean. Furthermore, 95\% prediction interval (PI high) based on the sample showed that there is a $95 \%$ probability that a future observation will be contain within the prediction interval. Conversely, there is also a $5 \%$ probability that the next observation will not be contained within the interval. A prediction interval is a range of values that is likely to contain the value of a single new observation given specified settings of the predictors. Prediction interval account for the variability around the mean response inherent in any prediction (Scheffé, 1963). Thus, $0.00 \mathrm{~g}$ of millet, $70.36 \mathrm{~g}$ of mungbean and 29.63 $\mathrm{g}$ of tigernut yielded the best breakfast product.

\section{CONCLUSION}

The three component argumented simplex centroid experimental designed of the response surface methodology (RSM) was adequate in modelling and optimization of the protein, carbohydrate, moisture content of the breakfast meal. Also, the RSM also predicted the oxalate, phytate and the tannin adequately. The predictive equations were generated for all the parameters investigated. The response surface plots (3D) graphically represented the linear, binary and ternary interaction of the millet, mungbean and tigernut flours. A good correlation was obtained between the predicted and actual (experimental) values, which validated the developed models. The optimum quantity of the blends in the breakfast food selected at a desirability of 0.464 were $0.00 \mathrm{~g}$ millet, $70.36 \mathrm{~g}$ mungbean and $29.63 \mathrm{~g}$ tigernut; suggesting that blends of the above will give the best breakfast product. The developed model would be of great importance to the food manufacturers to maximize the nutritive needs of consumers who are protein, mineral and energy deficient. This product would be of health importance to cancer patients.

COMPLIANCE WITH ETHICAL STANDARDS STATEMENT

\section{Declaration of Interest: None}

\section{Ethical Statement}

Hereby, I consciously assure that for the manuscript "Modelling and optimization of proximate and anti-nutritional composition of breakfast cereals produced from blends of millet, mungbean and tigernut flour using response surface methodology", the following is fulfilled:

1. This material is the authors' own original work, which has not been previously published elsewhere.

2. The paper is not currently being considered for publication elsewhere.

3. The paper reflects the authors' own research and analysis in a truthful and complete manner.

4. The paper properly credits the meaningful contributions of co-authors and co-researchers.

5. The results are appropriately placed in the context of prior and existing research.

6. All sources used are properly cited

\section{Consent Statement}

I hereby declare that we participated in the study and in the development of the manuscript titled "Modelling and optimization of proximate and anti-nutritional composition of breakfast cereals produced from blends of millet, mungbean and tigernut flour using response surface methodology". Authors and co-authors have read the final version and give our consent for the article to be published.

\section{Data Availability Statement}

Authors can confirm that all relevant data are within the article.

\section{ACKNOWLEDGEMENTS}

I sincerely express my gratitude to the Almighty God for His infinite mercy, direction, protection, guidance, provision and love throughout the duration of this study.

\section{Author Statement}

Eweama, A.U.: Conceptualization, Writing-Original draft, Writing-Reviewing and Editing, Investigation, Formal Analysis.

Nwosu, J.N.:Supervision, Resources. 
Owuamanam, C.I.:Supervision, Resources.

Obeleagu, S.O.: Methodology, Validation.

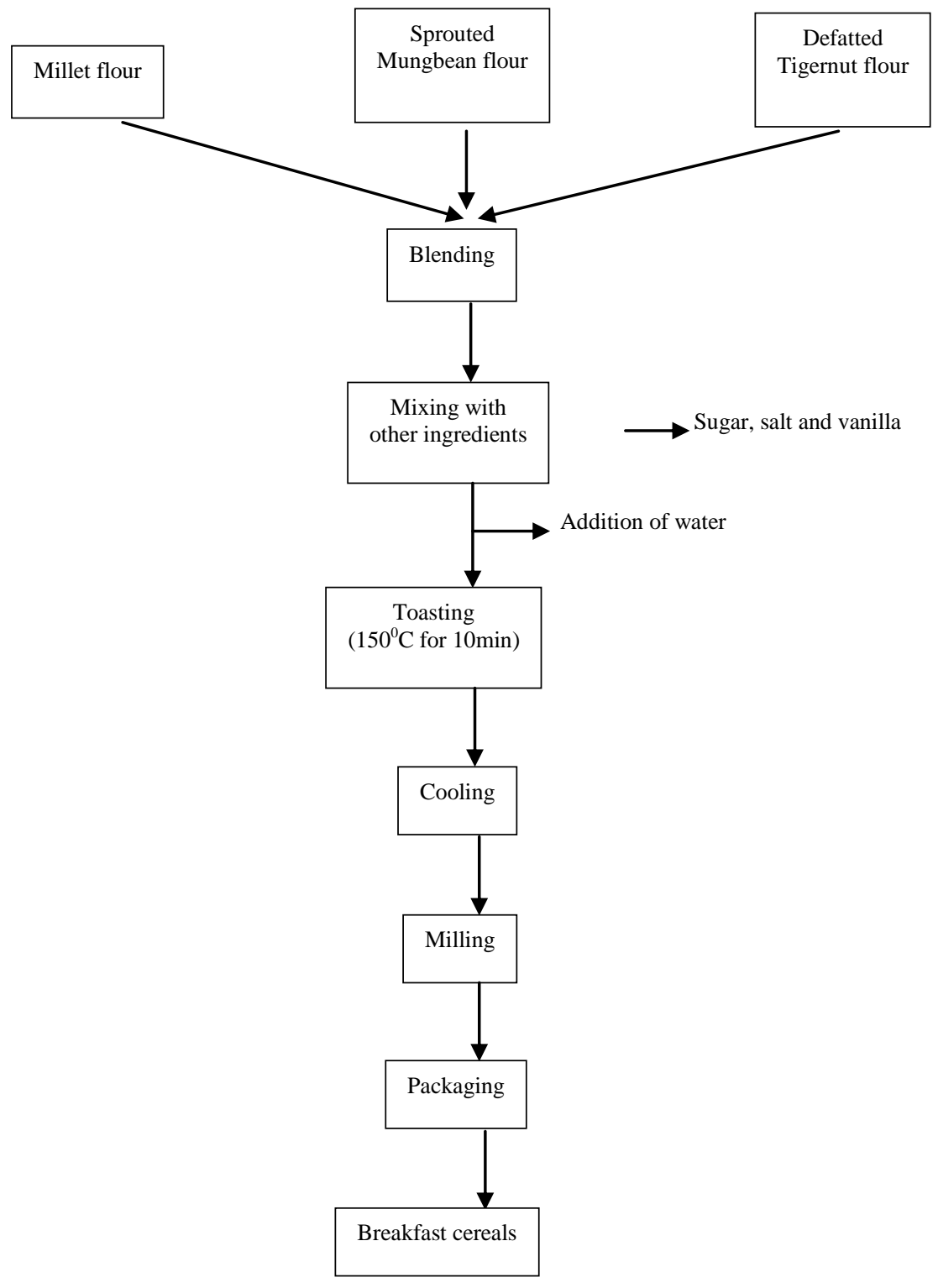

Figure 1: Modified flow diagram for the production of breakfast cereals from blends of Millet, mungbean and tigernut flours Source: Okafor \& Usman (2013) 


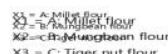

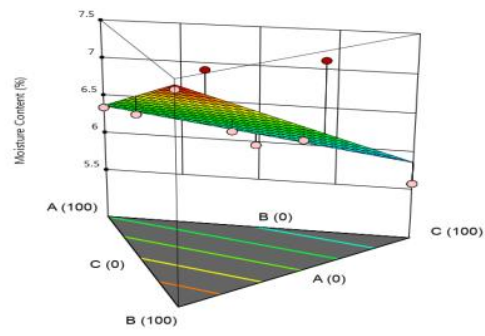

Figure 2: 3-D surface plot for the moisture content of breakfast cereals

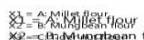

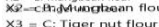

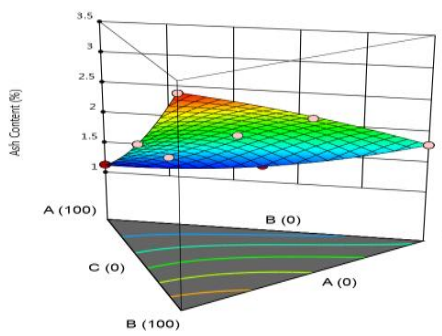

Figure 3: 3-D surface plot for the ash content of breakfast cereals

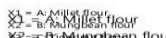

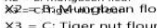

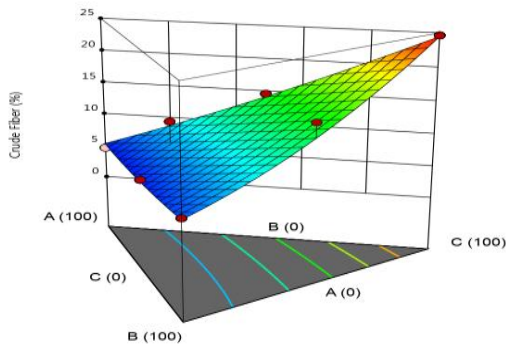

Figure 4: 3-D surface plot for the crude fiber of breakfast cereals

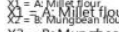

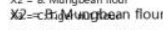

$\mathrm{x}_{3}=\mathrm{C}$ : Tiger nut flour

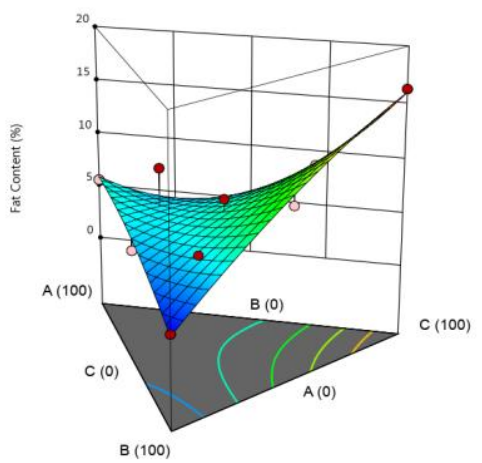

Figure 5: 3-D surface plot for the fat content of breakfast cereals

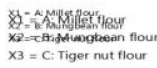

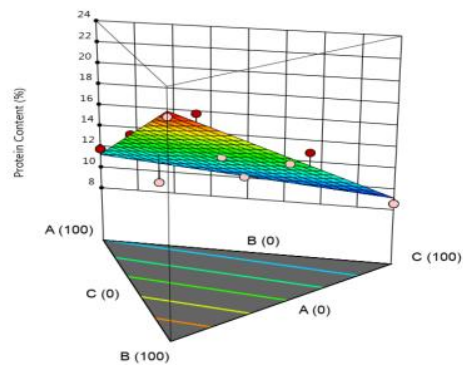

Figure 6: 3-D surface plot for the protein content of breakfast cereals

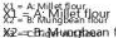

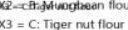

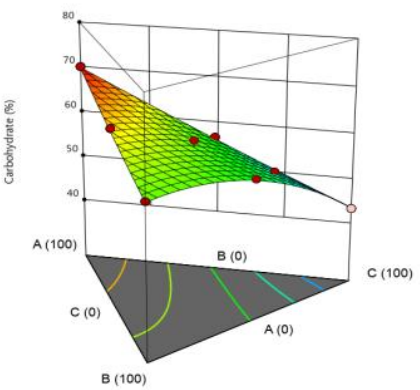

Figure 7: 3-D surface plot for the carbohydrate content of breakfast cereals

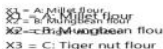

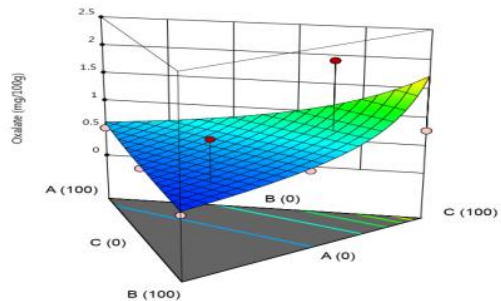

Figure 8: 3-D surface plot for the oxalate of breakfast cereals

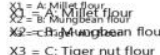

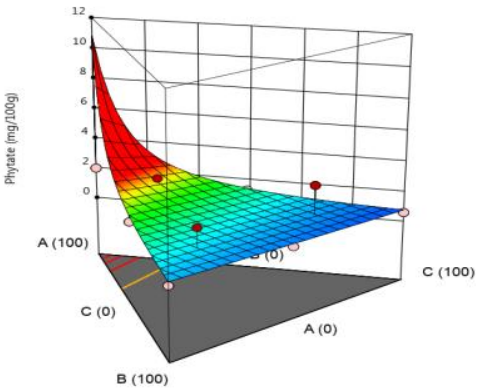

Figure 9: 3-D surface plot for the phytate of breakfast cereals 


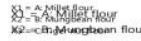

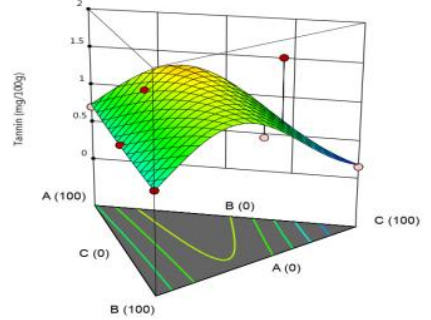

Figure 10: 3-D surface plot for the tannin of breakfast cereals Design-Expertø Software

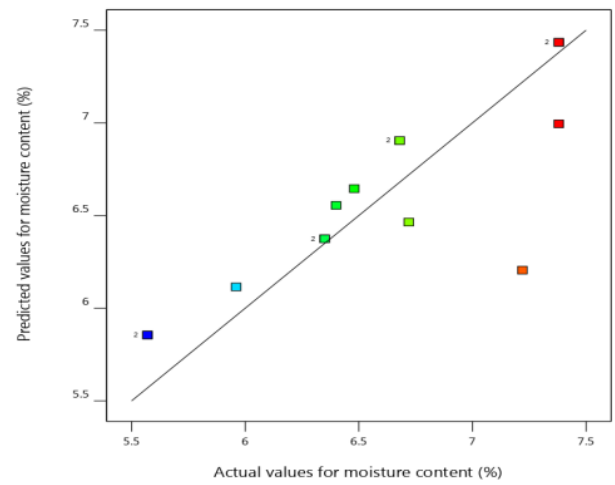

Figure 11: Graph of predicted against actual values for the moisture content of breakfast cereals

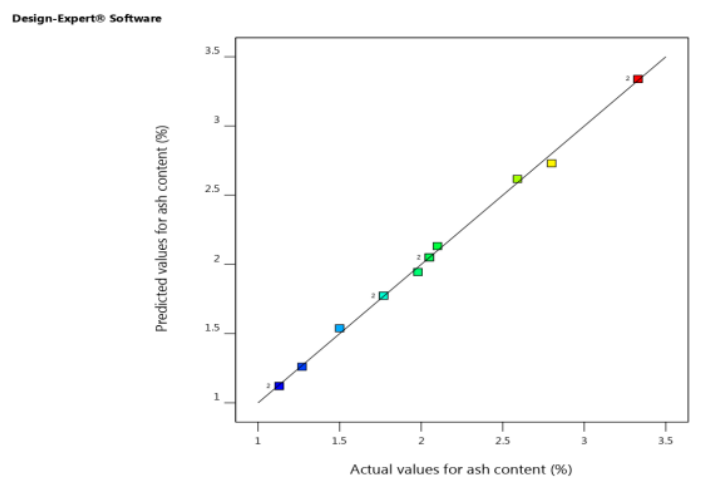

Figure 12: Graph of predicted against actual values for the ash content of breakfast cereals

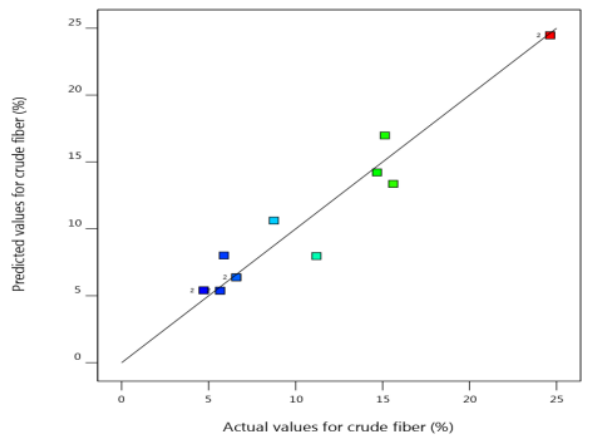

Figure 13: Graph of predicted against actual values for the crude fiber of breakfast cereals

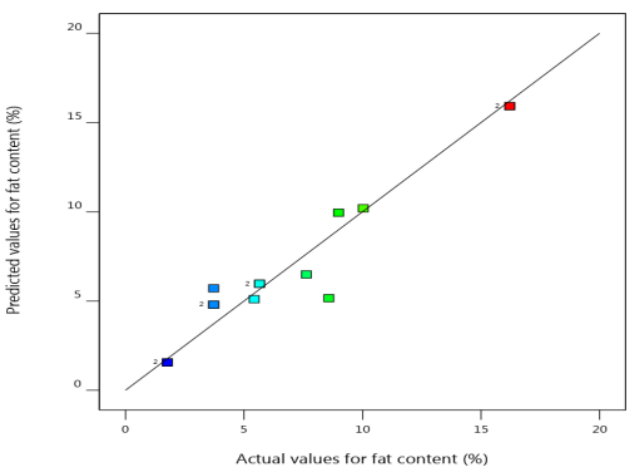

Figure 14: Graph of predicted against actual values for the fat content of breakfast cereals

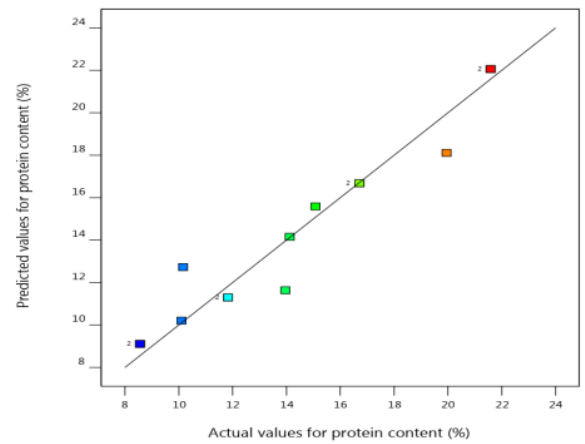

Figure 15: Graph of predicted against actual values for the protein content of breakfast cereals

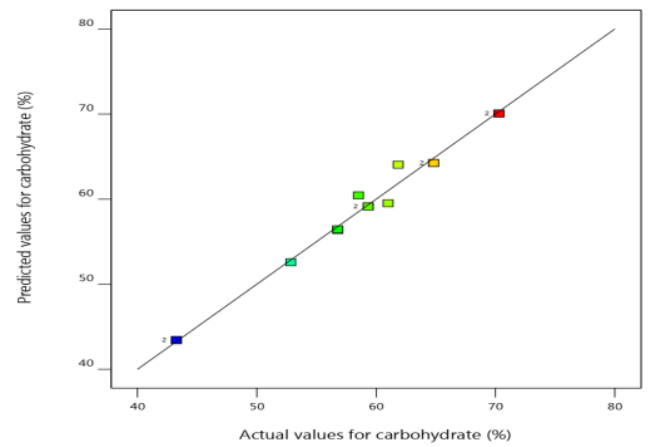

Figure 16: Graph of predicted against actual values for the carbohydrate content of breakfast cereals

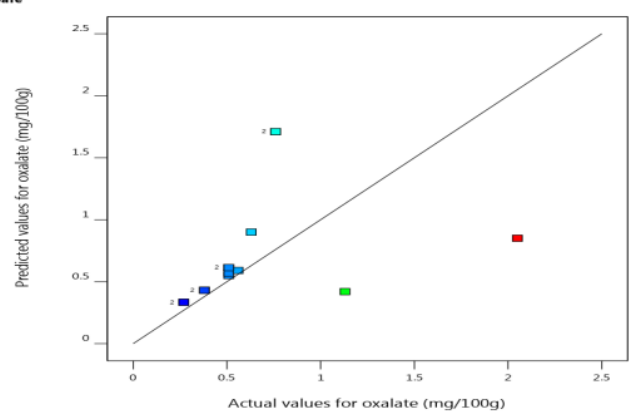

Figure 17: Graph of predicted against actual values for oxalate of breakfast cereals 


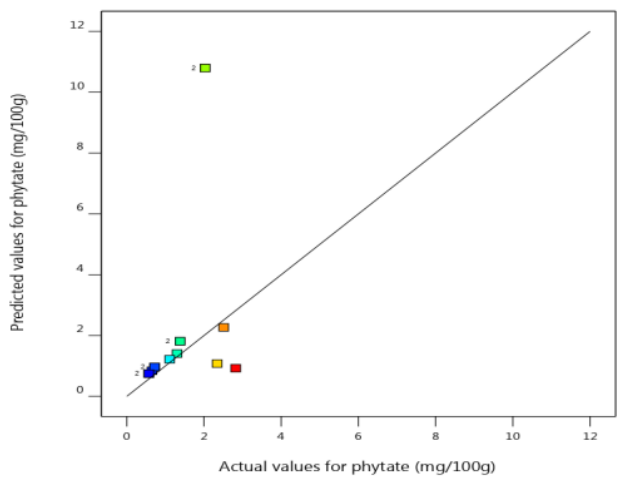

Figure 18: Graph of predicted against actual values for phytate of breakfast cereals

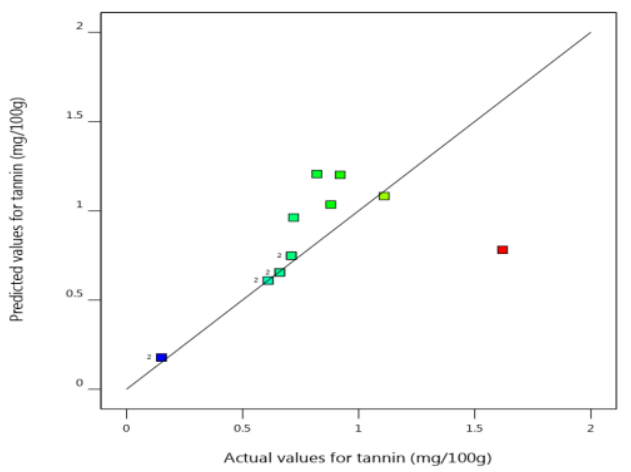

Figure 19: Graph of predicted against actual values for tannin of breakfast cereals
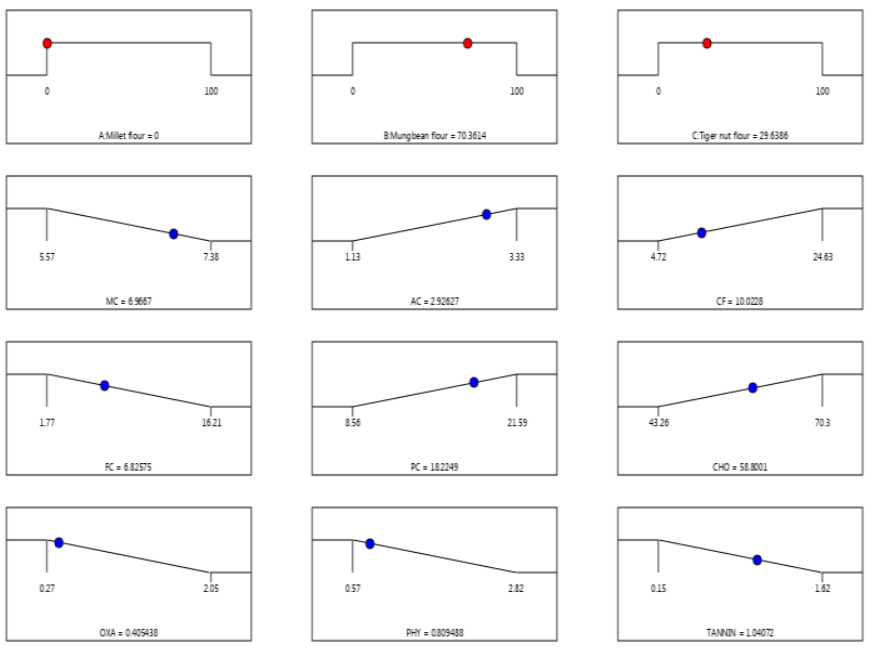

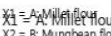

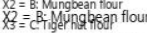
$x_{3}=$ C: Tiger nut flour

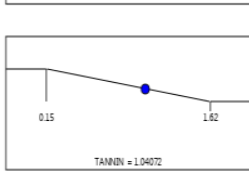

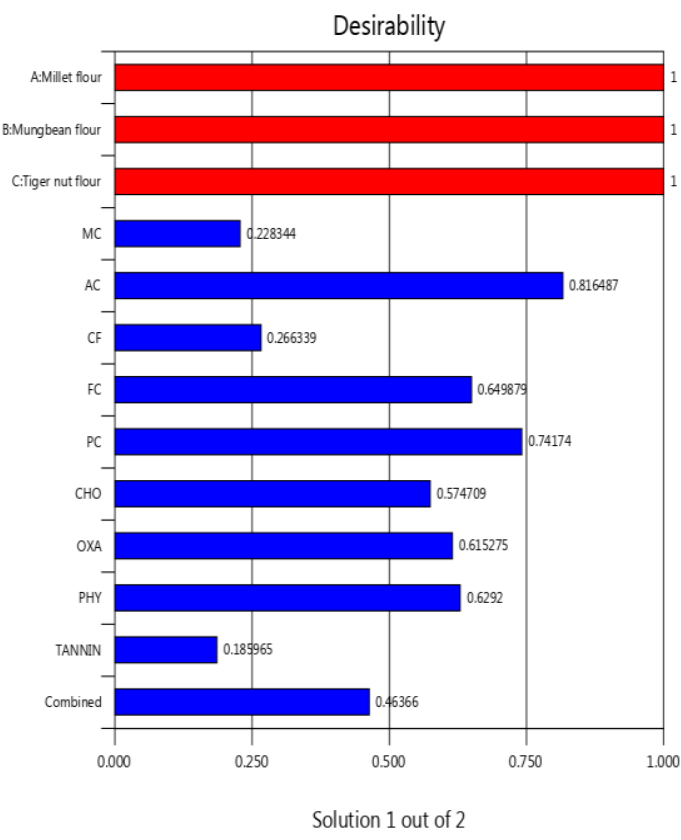

Figure 21: Desirability bar graph

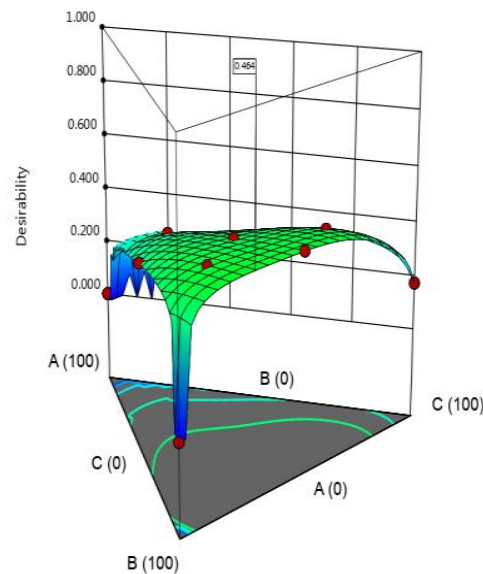

Figure 22: 3-D desirability plot
Desirability $=0.464$ Solution 1 out of 2

Figure 20: Numerical optimization ramps view for the variables 
Table1: Three component augmented simplex centroid design matrix for modelling and optimization of the proximate and anti-nutritional composition of breakfast cereals produced from blends of millet, mungbean and tigernut flour

\begin{tabular}{|c|c|c|c|c|c|c|c|c|c|c|c|c|}
\hline \multirow{2}{*}{$\begin{array}{c}\text { Design } \\
\text { point }\end{array}$} & \multicolumn{3}{|c|}{ Independent variables } & \multicolumn{10}{|c|}{ Dependent variables } \\
\cline { 2 - 13 } & $\begin{array}{c}x_{1} \\
(\mathrm{~g})\end{array}$ & $\begin{array}{c}x_{2} \\
(\mathrm{~g})\end{array}$ & $\begin{array}{c}x_{3} \\
(\mathrm{~g})\end{array}$ & $\begin{array}{c}\mathrm{MC} \\
(\%)\end{array}$ & $\begin{array}{c}\mathrm{AC} \\
(\%)\end{array}$ & $\begin{array}{c}\mathrm{CF} \\
(\%)\end{array}$ & $\begin{array}{c}\mathrm{FC} \\
(\%)\end{array}$ & $\begin{array}{c}\text { PC } \\
(\%)\end{array}$ & $\begin{array}{c}\text { CHO } \\
(\%)\end{array}$ & $\begin{array}{c}\text { Oxalate } \\
(\mathrm{mg} / 100 \mathrm{~g})\end{array}$ & $\begin{array}{c}\text { Phytate } \\
(\mathrm{mg} / 100 \mathrm{~g})\end{array}$ & $\begin{array}{c}\text { Tannin } \\
(\mathrm{mg} / 100 \mathrm{~g})\end{array}$ \\
\hline 1 & 100 & 0 & 0 & 6.35 & 1.13 & 4.72 & 5.66 & 11.83 & 70.30 & 0.51 & 2.03 & 0.71 \\
\hline 2 & 0 & 100 & 0 & 7.38 & 3.33 & 6.59 & 1.77 & 21.59 & 59.33 & 0.27 & 0.72 & 0.61 \\
\hline 3 & 0 & 0 & 100 & 5.57 & 1.77 & 24.63 & 16.21 & 8.56 & 43.26 & 0.76 & 0.57 & 0.15 \\
\hline 4 & 50 & 50 & 0 & 6.68 & 2.05 & 5.66 & 3.72 & 16.71 & 64.82 & 0.38 & 1.38 & 0.66 \\
\hline 5 & 50 & 0 & 50 & 5.96 & 1.27 & 14.68 & 3.72 & 10.10 & 56.78 & 0.63 & 1.30 & 0.92 \\
\hline 6 & 0 & 50 & 50 & 6.48 & 2.59 & 15.61 & 8.99 & 15.08 & 56.78 & 0.51 & 0.65 & 0.88 \\
\hline 7 & 33.3 & 33.3 & 33.3 & 6.40 & 2.10 & 8.75 & 7.63 & 14.12 & 61.00 & 0.51 & 1.11 & 0.82 \\
\hline 8 & 66.6 & 16.6 & 16.6 & 6.72 & 1.50 & 11.20 & 8.58 & 10.16 & 61.85 & 0.56 & 2.51 & 1.11 \\
\hline 9 & 16.6 & 66.6 & 16.6 & 7.38 & 2.80 & 5.88 & 5.43 & 19.95 & 58.52 & 1.13 & 2.34 & 0.72 \\
\hline 10 & 16.6 & 16.6 & 66.6 & 7.22 & 1.98 & 15.13 & 10.03 & 13.96 & 52.85 & 2.05 & 2.82 & 1.62 \\
\hline 11 & 100 & 0 & 0 & 6.35 & 1.13 & 4.72 & 5.66 & 11.83 & 70.30 & 0.51 & 2.03 & 0.71 \\
\hline 12 & 0 & 100 & 0 & 7.38 & 3.33 & 6.59 & 1.77 & 21.59 & 59.33 & 0.27 & 0.72 & 0.61 \\
\hline 13 & 0 & 0 & 100 & 5.57 & 1.77 & 24.63 & 16.21 & 8.56 & 43.26 & 0.76 & 0.57 & 0.15 \\
\hline 14 & 50 & 50 & 0 & 6.87 & 2.05 & 5.66 & 3.72 & 16.71 & 64.82 & 0.38 & 1.38 & 0.66 \\
\hline
\end{tabular}

Key: MC- Moisture Content; AC- Ash Content; CF- Crude Fiber; FC- Fat Content; PC- Protein Content; CHO- Carbohydrate content. $\mathrm{X}_{1}$ - milletflour;

$\mathrm{X}_{2}$ - mungbeanflour; $\mathrm{X}_{3}$ - tigernut flour.

Table 2: Regression equation coefficients for modelling and optimization of the proximate and anti-nutritional composition of breakfast cereals produced from blends of millet, mungbean and tigernut flour

\begin{tabular}{|c|c|c|c|c|c|c|c|c|c|}
\hline \multirow[b]{2}{*}{ Coefficient } & \multicolumn{9}{|c|}{ Dependent variables } \\
\hline & $\begin{array}{l}\mathrm{MC} \\
(\%)\end{array}$ & $\begin{array}{l}\mathrm{AC} \\
(\%)\end{array}$ & $\begin{array}{l}\mathrm{CF} \\
(\%)\end{array}$ & $\begin{array}{l}\mathrm{FC} \\
(\%)\end{array}$ & $\begin{array}{l}\mathrm{PC} \\
(\%)\end{array}$ & $\begin{array}{c}\mathrm{CHO} \\
(\%)\end{array}$ & $\begin{array}{c}\text { Oxalate } \\
(\mathrm{mg} / 100 \mathrm{~g})\end{array}$ & $\begin{array}{c}\text { Phytate } \\
(\mathrm{mg} / 100 \mathrm{~g})\end{array}$ & $\begin{array}{c}\text { Tannin } \\
(\mathrm{mg} / 100 \mathrm{~g})\end{array}$ \\
\hline \multicolumn{10}{|l|}{ Linear } \\
\hline $\begin{array}{c}x_{1} \\
\text { (p-value) }\end{array}$ & $\begin{array}{c}6.37^{*} \\
(0.002)\end{array}$ & $\begin{array}{c}1.12 * \\
(<0.0001)\end{array}$ & $\begin{array}{c}5.40 * \\
(<0.0001)\end{array}$ & $\begin{array}{c}5.96^{*} \\
(<0.0001)\end{array}$ & $\begin{array}{c}11.30 * \\
(<0.0001)\end{array}$ & $\begin{array}{c}70.06^{*} \\
(<0.0001)\end{array}$ & $\begin{array}{c}1.83^{*} \\
(0.008)\end{array}$ & $\begin{array}{l}0.27 * \\
(0.01)\end{array}$ & $\begin{array}{l}-0.34^{*} \\
(0.01)\end{array}$ \\
\hline $\begin{array}{c}x_{2} \\
\text { (p-value) }\end{array}$ & $\begin{array}{c}7.43^{*} \\
(0.002)\end{array}$ & $\begin{array}{c}3.33 * \\
(<0.0001)\end{array}$ & $\begin{array}{c}6.38^{*} \\
(<0.0001)\end{array}$ & $\begin{array}{c}1.56^{*} \\
(<0.0001)\end{array}$ & $\begin{array}{c}22.06^{*} \\
(<0.0001)\end{array}$ & $\begin{array}{c}59.14 * \\
(<0.0001)\end{array}$ & $\begin{array}{c}3.12^{*} \\
(0.008)\end{array}$ & $\begin{array}{l}1.15^{*} \\
(0.01)\end{array}$ & $\begin{array}{l}-0.55^{*} \\
(0.01)\end{array}$ \\
\hline $\begin{array}{c}x_{3} \\
\text { (p-value) }\end{array}$ & $\begin{array}{c}5.85^{*} \\
(0.002) \\
\end{array}$ & $\begin{array}{c}1.77 * \\
(<0.0001) \\
\end{array}$ & $\begin{array}{c}24.46^{*} \\
(<0.0001) \\
\end{array}$ & $\begin{array}{c}15.92 * \\
(<0.0001)\end{array}$ & $\begin{array}{c}9.11^{*} \\
(<0.0001)\end{array}$ & $\begin{array}{c}43.43^{*} \\
(<0.0001) \\
\end{array}$ & $\begin{array}{c}0.89^{*} \\
(0.008) \\
\end{array}$ & $\begin{array}{l}1.43^{*} \\
(0.01)\end{array}$ & $\begin{array}{l}-1.78^{*} \\
(0.01) \\
\end{array}$ \\
\hline \multicolumn{10}{|l|}{ Binary } \\
\hline $\begin{array}{c}x_{1} x_{2} \\
\text { (p-value) }\end{array}$ & - & $\begin{array}{c}-0.71 * \\
(0.0009)\end{array}$ & $\begin{array}{c}-2.03 \\
(0.750)\end{array}$ & $\begin{array}{c}4.13 \\
(0.457)\end{array}$ & - & $\begin{array}{c}-1.42 \\
(0.732)\end{array}$ & - & - & $\begin{array}{l}-0.12 \\
(0.91)\end{array}$ \\
\hline $\begin{array}{c}x_{1} x_{3} \\
\text { (p-value) }\end{array}$ & - & $\begin{array}{l}-0.74 * \\
(0.002)\end{array}$ & $\begin{array}{c}-2.86 \\
(0.709)\end{array}$ & $\begin{array}{l}-20.93^{*} \\
(0.010)\end{array}$ & - & $\begin{array}{l}-1.536 \\
(0.758)\end{array}$ & - & - & $\begin{array}{c}4.77^{*} \\
(0.006)\end{array}$ \\
\hline $\begin{array}{c}x_{2} x_{3} \\
(\mathrm{p} \text {-value })\end{array}$ & - & $\begin{array}{c}0.24 \\
(0.183)\end{array}$ & $\begin{array}{c}-8.24 \\
(0.298)\end{array}$ & $\begin{array}{c}4.83 \\
(0.467)\end{array}$ & - & $\begin{array}{l}20.68^{*} \\
(0.002)\end{array}$ & - & - & $\begin{array}{l}4.58^{*} \\
(0.008)\end{array}$ \\
\hline \multicolumn{10}{|l|}{ Ternary } \\
\hline $\begin{array}{c}x_{1} x_{2} x_{3} \\
\text { (p-value) }\end{array}$ & - & $\begin{array}{c}5.12^{*} \\
(0.002)\end{array}$ & - & - & - & - & - & - & - \\
\hline$R^{2}$ & 0.6783 & 0.9986 & 0.9549 & 0.9254 & 0.9344 & 0.9864 & 0.5772 & 0.5371 & 0.8453 \\
\hline $\operatorname{Adj} R^{2}$ & 0.6198 & 0.9974 & 0.9267 & 0.8788 & 0.9225 & 0.9778 & 0.5003 & 0.4529 & 0.7486 \\
\hline LOF & NS & NS & NS & NS & NS & NS & NS & NS & NS \\
\hline $\mathrm{CV}(\%)$ & 1.17 & 1.82 & 17.08 & 22.77 & 8.74 & 2.08 & 33.07 & 41.04 & 72.12 \\
\hline Model & $0.0020^{*}$ & $<0.0001^{*}$ & $<0.0001^{*}$ & $0.0003^{*}$ & $<0.0001^{*}$ & $<0.0001^{*}$ & $0.0088^{*}$ & $0.0145^{*}$ & $0.0042 *$ \\
\hline
\end{tabular}

Key: LOT-Lack of Fit; * Significant at the $5 \%$ level ( $<<0.05)$. NS - Not Significant; CV-Coefficient of Variation; $x_{1}-$ milletflour; $x_{2}-$ mungbeanflour; $x_{3}-$ tigernut flour. 
Table 3: Numerical optimization criteria for modelling and optimization of the proximate and anti-nutritional composition of breakfast cereals produced from blends of millet, mungbean and tigernut flour

\begin{tabular}{|c|c|c|c|c|c|c|}
\hline Variables & Goal & Lower limit & Upper limit & Lower weight & Upperweight & Importance \\
\hline \multicolumn{7}{|l|}{ Independent Variables } \\
\hline Millet flour (g) & is in range & 0 & 100 & 1 & 1 & 3 \\
\hline Mungbean flour (g) & is in range & 0 & 100 & 1 & 1 & 3 \\
\hline Tigernut flour (g) & is in range & 0 & 100 & 1 & 1 & 3 \\
\hline \multicolumn{7}{|l|}{ Dependent Variables } \\
\hline Moisture content(\%) & minimize & 5.57 & 7.38 & 1 & 1 & 3 \\
\hline Ash content $(\%)$ & maximize & 1.13 & 3.33 & 1 & 1 & 3 \\
\hline Crude fiber(\%) & maximize & 4.72 & 24.63 & 1 & 1 & 3 \\
\hline Fat content $(\%)$ & minimize & 1.77 & 16.21 & 1 & 1 & 3 \\
\hline Protein content $(\%)$ & maximize & 8.56 & 21.59 & 1 & 1 & 3 \\
\hline Carbohydrate (\%) & maximize & 43.26 & 70.3 & 1 & 1 & 3 \\
\hline Oxalate $(\mathrm{mg} / 100 \mathrm{~g})$ & minimize & 2.05 & 0.27 & 1 & 1 & 3 \\
\hline Phytate (mg/100g) & minimize & 2.82 & 0.57 & 1 & 1 & 3 \\
\hline Tannin $(\mathrm{mg} / 100 \mathrm{~g})$ & minimize & 0.15 & 1.62 & 1 & 1 & 3 \\
\hline
\end{tabular}

Table 4: Optimization value, prediction and desirability for modelling and optimization of the proximate and anti-nutritional composition of breakfast cereals produced from blends of millet, mungbean and tigernut flour

\begin{tabular}{|c|c|c|c|c|c|c|c|c|c|c|c|c|c|c|}
\hline $\begin{array}{c}\mathrm{S} / \\
\mathrm{N}\end{array}$ & $\begin{array}{c}\text { Mille } \\
\mathrm{t} \\
(\mathrm{g})\end{array}$ & $\begin{array}{c}\text { Mung } \\
(\mathrm{g})\end{array}$ & $\begin{array}{c}\mathrm{TF} \\
(\mathrm{g})\end{array}$ & $\begin{array}{c}\mathrm{MC} \\
(\%)\end{array}$ & $\begin{array}{c}\mathrm{AC} \\
(\%)\end{array}$ & $\begin{array}{c}\mathrm{CF} \\
(\%)\end{array}$ & $\begin{array}{c}\mathrm{FC} \\
(\%)\end{array}$ & $\begin{array}{c}\mathrm{PC} \\
(\%)\end{array}$ & $\begin{array}{c}\mathrm{CHO} \\
(\%)\end{array}$ & $\begin{array}{c}\text { Oxalate } \\
(\mathrm{mg} / 100 \\
\mathrm{g})\end{array}$ & $\begin{array}{c}\text { Phytate } \\
(\mathrm{mg} / 100 \\
\mathrm{g})\end{array}$ & $\begin{array}{c}\text { Tannin } \\
(\mathrm{mg} / 100 \\
\mathrm{g})\end{array}$ & $\begin{array}{c}\text { DES } \\
\mathrm{n}\end{array}$ & $\begin{array}{c}\text { Selectio } \\
\mathrm{n}\end{array}$ \\
\hline 1 & 0.00 & 70.36 & $\begin{array}{c}29.6 \\
3\end{array}$ & 6.96 & 2.92 & $\begin{array}{c}10.0 \\
2\end{array}$ & 6.82 & 18.22 & 58.80 & 0.40 & 0.80 & 1.04 & 0.464 & Selected \\
\hline 2 & 20.40 & 79.60 & 0.00 & 7.21 & 2.77 & 5.85 & 3.13 & 19.86 & 61.13 & 0.34 & 1.02 & 0.58 & 0.402 & \\
\hline
\end{tabular}

Key: Mung- Mungbean flour; TF- Tigernut flour; MC- Moisture Content; AC- Ash Content; CF- Crude Fiber; FC- Fat Content; PC- Protein Content; CHOCarbohydrate; DES- Desirability

Table 5: Confirmation of optimum values (Two-sided Confidence $=95 \%$ ) for modelling and optimization of the proximate and anti-nutritional composition of breakfast cereals produced from blends of millet, mungbean and tigernut flour

\begin{tabular}{|c|c|c|c|c|c|c|c|c|c|}
\hline Response & Predicted Mean & Predicted Median & Observed & Std Dev & $\mathrm{n}$ & SE Pred & 95\% PI low & Data Mean & 95\% PI high \\
\hline MC & 6.55502 & 6.55502 & 6.4 & 0.380161 & 6 & 0.393563 & 5.6888 & 6.58 & 7.42125 \\
\hline AC & 2.13257 & 2.13257 & 2.1 & 0.0374603 & 6 & 0.0473228 & 2.02067 & 2.06 & 2.24447 \\
\hline CF & 10.6245 & 10.6245 & 8.75 & 1.88447 & 6 & 2.08397 & 5.81886 & 11.03 & 15.4302 \\
\hline FC & 6.48707 & 6.48707 & 7.63 & 1.61205 & 6 & 1.78271 & 2.37612 & 7.08 & 10.598 \\
\hline PC & 14.1591 & 14.1591 & 14.12 & 1.25333 & 6 & 1.29751 & 11.3033 & 14.34 & 17.0149 \\
\hline CHO & 59.5172 & 59.5172 & 61 & 1.22412 & 6 & 1.35372 & 56.3956 & 58.80 & 62.6389 \\
\hline OXA & 0.569763 & 0.511639 & 0.51 & 0.191039 & 6 & 0.18675 & 0.289388 & 1.99 & 2.20535 \\
\hline PHY & 1.21895 & 1.04862 & 1.11 & 0.486454 & 6 & 0.48231 & 0.546629 & 0.93 & 12.8407 \\
\hline TANNIN & 1.20597 & 1.14119 & 0.82 & 0.412044 & 6 & 0.39207 & 0.489046 & 0.92 & 2.66298 \\
\hline
\end{tabular}

Std Dev - Standard Deviation, SE Pred - Standard Error Predicted, PI - Prediction Interval, n- number of confirmations run

\section{REFERENCES}

[1] Abbey, B. W., \& Ibeh, G. O. (1988). Functional properties of raw and heat processed Cowpea (Vigna unguiculata, Walp) flour. Journal of Food Science, 53(6), 1775-1777. https://doi.org/10.1111/j.1365-2621.1988.tb07840.x

[2] Adejuyitan, J. A. (2011). Tigernut Processing: Its Food uses and Health Benefits. American Journal of Food Technology, 6(3), 197-201.DOI:10.3923/ajft.2011.197.201
[3] Aiyesanmi, A. F. and Oguntokun, M. O., (1996.). Nutrient composition of Dioclea reflexa seed:An underutilized edible legume.Rivista Italiana delle Sostanze Grasse,73, 521523.http://pascal-

francis.inist.fr/vibad/index.php?action=getRecordDetail\&idt=2552 $\underline{580}$

[4] Ali, M.A.M., \&EI-Tinay, A.H., (2003).Effect of fermentation on the Invitro protein digestibility of pearl millet. Food Chemistry,80(1):51-54.DOI: 10.1016/s0308-8146(02)00234-0 
[5] Anderson, J. W., Smith, B. M., \& Washnock, C. S. (1999). Cardiovascular and renal benefits of dry bean and soybean intake. The American Journal of Clinical Nutrition, 70(3 Suppl), 464S474S. https://doi.org/10.1093/ajcn/70.3.464s

[6] Anwar, F., Latif, S., Przybylski, R., Sultana, B., \& Ashraf, M. (2007). Chemical composition and antioxidant activity of seeds of different cultivars of mungbean. Journal of Food Science, 72(7), S503-10.https://doi.org/10.1111/j.1750-3841.2007.00462.x

[7] AOAC (2015). Official Methods of Analysis(18th edition), Association ofOfficial Analytical Chemist, Washington, DC., USA.

[8] Awolu, O. O., Oluwaferanmi, P. M., Fafowora, O. I., \& Oseyemi, G. F. (2015). Optimization of the extrusion process for the production of ready-to-eat snack from rice, cassava and kersting's groundnut composite flours. Lebensmittel-Wissenschaft Und Technologie Food Science and Technology, 64(1), 1824.https://doi.org/10.1016/j.1wt.2015.05.025

[9] Belewu, M. A., \& Abodunrin, O. A. (2008). Preparation of kunnu from unexploited rich food source: Tiger nut (Cyperus esculentus). Pakistan Journal of Nutrition: PJN, 7(1), 109-111.DOI: 10.3923/pjn.2008.109.111

[10] Brown, K. H., (1991). The importance of dietary quality versus quantity for weanlings in the developed countries. A Framework for Discussion. Food and Nutrition Bulletin, 13 (2), 8693.https://doi.org/10.1177/156482659101300219

[11] Butt, M. S., \& Batool, R. (2010). Nutritional and functional properties of some promising legumes protein isolates. Pakistan Journal of Nutrition: PJN, 9(4), 373-379.DOI: 10.3923/pjn.2010.373.379

[12] Chung, K. T., Wong, T. Y., Wei, C. I., Huang, Y. W., \& Lin, Y. (1998). Tannins and human health: a review. Critical Reviews in Food Science and Nutrition, 38(6), 421464.https://doi.org/10.1080/10408699891274273

[13] Cornell, J.A. (1986). A comparison between two ten-point designs for studying three component mixture systems. Journal of Quality Technology, https://doi.org/10.1080/00224065.1986.11978980

[14] Dongyan, T., Yinmao, D., Hankun, R., Li, L., \&Congfen, H. (2014). A review of phytochemistry, metabolite changes, and medicinal uses of the common food mung bean and its sprouts (Vigna radiata). Chemistry Central Journal, 8(1),4.DOI: 10.1186/1752-153X-8-4

[15] Eshun, G., (2012). Nutrient composition and functional properties of bean flours of three soya bean varieties from Ghana. African Journal of Food Science and Technology.3(8), 176181.http://www.interesjournals.org/AJFST

[16] Franziska Spritzler (2017) Oxalate (oxalic acid): good or bad? www.healthline.com

[17] Freeny, A., Box, G. E. P., \& Draper, N. R. (1988). Empirical model building and response surfaces. Technometrics: A Journal of Statistics for the Physical, Chemical, and Engineering Sciences, $30(2)$, 229.https://www.tandfonline.com/doi/abs/10.1080/00401706.1988 .10488371

[18] Gee, M.C., \& Harold, G.W. (2004). An assessment of the Tannin content of wild sorghum. Journal of Food Science, 43, 1850-1870.

[19] Ghavidel, R.A.,\& Davoodi, M.G. (2014). Processing and assessment of quality characteristics of composite baby foods.World Academic Science Engineering Technology, 59, 2043. doi.org/10.5281/zenodo. 1078907

[20] Graf, E., Empson, K.L., \&Eaton, J.W. (1987). Phytic acid: A natural anti-oxidant. Journal of Biological Chemistry, 262(24), 11647-11650.https://doi.org/10.1016/S0021-9258(18)60858-0

[21] Southgate, D. A. T., \& Greenfield, H. (1988). Guidelines for the production, management and use of food composition data: An in foods project. Food Sciences and Nutrition, 42(1), 1523.https://doi.org/10.1080/09543465.1988.11904124

[22] Habauzit, V., \& Morand, C. (2012). Evidence for a protective effect of polyphenols-containing foods on cardiovascular health: an update for clinicians. Therapeutic Advances in Chronic Disease, 3(2), 87-106.https://doi.org/10.1177/2040622311430006
[23] Haines, P. S., Guilkey, D. K., \& Popkin, B. M. (1996). Trends in breakfast consumption of US adults between 1965 and 1991. Journal of the American Dietetic Association, 96(5), 464470.https://doi.org/10.1016/S0002-8223(96)00130-7

[24] Huang, W.-Y., Cai, Y.-Z., \& Zhang, Y. (2010). Natural phenolic compounds from medicinal herbs and dietary plants: potential use for cancer prevention. Nutrition and Cancer, 62(1), 120.https://doi.org/10.1080/01635580903191585

[25] Jacobs, D. R., Jr, Meyer, K. A., Kushi, L. H., \& Folsom, A. R. (1998). Whole-grain intake may reduce the risk of ischemic heart disease death in postmenopausal women: the Iowa Women's Health Study. The American Journal of Clinical Nutrition, 68(2), 248-257.https://doi.org/10.1093/ajcn/68.2.248

[26] Jideani. V. A. (2005). Characteristics of local pearl millet (Pennisetum glaucum) grains. Nigeria Food Journal, 23, 193204.DOI: 10.4314/nifoj.v23i1.33617

[27] Jones, J. M. (2003). Cereal Nutrition. Statistical Society, 25, 235 251.

[28] Kaur, K. D., Jha, A., Sabikhi, L., \& Singh, A. K. (2014). Significance of coarse cereals in health and nutrition: a review. Journal of Food Science and Technology, 51(8), 14291441.https://doi.org/10.1007/s13197-011-0612-9

[29] Kirk, R. S. and Sawyer, R. (1991). Pearson's Composition and Analysis of Foods, 9th ed. (student edition), England: Addision Wesley Longman Ltd. 33-36.

[30] Kushi, L.H., Meyer, K.A. \& Jacobs, D.R. (1999). Cereals, legumes, and chronic disease risk reduction: evidence from epidemiologic studies. American Journal of Clinical Nutrition, 70(3 Suppl):451S-458S. DOI: 10.1093/ajcn/70.3.451s

[31] Mateos-Aparicio, I., Redondo-Cuenca, A., Villanueva-Suárez, M.J., Zapata-Revilla, M.-A., \& Tenorio-Sanz, M.-D. (2010). Pea pod, broad bean pod and okara, potential sources of functional compounds. Lebensmittel-Wissenschaft Und Technologie Food Science and Technology, 43(9), 14671470.https://doi.org/10.1016/j.1wt.2010.05.008

[32] Mbaeyi, I.E., \&Onweluzo, J.C. (2010).Effect of sprouting and pregelatinization on the composition and sensory properties of flaked breakfast cereal produced from sorghum-pigeon pea blends. AgroScience, 9,3. DOI: 10.4314/as.v9i3.65758

[33] Mbaeyi-Nwaoha, I. E., \& Uchendu, N. O. (2016). Production and evaluation of breakfast cereals from blends of acha and fermented soybean paste (okara). Journal of Food Science and Technology, 53(1), 50-70.https://doi.org/10.1007/s13197-015-2032-8

[34] Messina, M. J. (1999). Legumes and soybeans: overview of their nutritional profiles and health effects. The American Journal of Clinical Nutrition, $70(3 \quad$ Suppl), 439S-450S. https://doi.org/10.1093/ajen/70.3.439s

[35] Morrison, S.C., \& Savage, G.P. (2003). Encyclopedia of Food Sciences and Nutrition (second edition)

[36] Moss, R.; Gore, P. J.; and Murray, I. C. (1987) "The Influence of Ingredients and Processing Variables on the Quality and Microstructure of Hokkien, Cantonese and Instant Noodles," Food Structure,https://digitalcommons.usu.edu/foodmicrostructure/vol6 $\underline{\text { iss } 1 / 9}$

[37] Mubarak, A.E. (2005). Nutritional Composition and antinutritional factors of mungbean seeds (Phaseolusaureus) as affected by some home traditional processors. Journal of Food Chemistry, 89, 489 495.DOI:10.1016/J.FOODCHEM.2004.01.007

[38] Gunst, R. F., Myers, R. H., \& Montgomery, D. C. (1996). Response surface methodology: Process and product optimization using designed experiments. Technometrics: A Journal of Statistics for the Physical, Chemical, and Engineering Sciences, 38(3), 285.https://doi.org/10.2307/1270613

[39] Myers, R.H., Montgomery, D.C., \&Anderson-Cook, C.M. (2009). Response Surface Methodology: Process and Product Optimization Using Designed Experiments. (4th edition) New York, USA, John Wiley \& Sons

[40] Okafor, G. I., \& Usman, G. O. (2014). Production and evaluation of breakfast cereals from blends of African yam bean (sphenostylis stenocarpa), maize (Zea mays) and defatted coconut (cocus nucifera): Production and evaluation of breakfast cereals. Journal 
of Food Processing and Preservation, 38(3), 10371043.https://doi.org/10.1111/jfpp. 12060

[41] Okaka, J.C. (2005). Handling, Storage and Processing of Plant Foods. OJC Academic Publishers, Enugu, pp 270-285

[42] Oladele, A. K., \& Aina, J. O. (2007). Chemical composition and functional properties of flour produced from two varieties of tigernut (Cyperus esculentus). African Journal of Biotechnology, 6(21), 2473-2476.https://doi.org/10.5897/AJB2007.000-2391

[43] Oladunmoye, Lineback, D.R. \& Ke, C.H., (2010). Evaluation of some physical-chemical properties of wheat, cassava, maize and cowpea flours for bread making.Journal of Food Quality, 33(6), 693-708. DOI: $10.1111 /$ j.1745-4557.2010.00351.x

[44] Onwuka, G.I. (2018). Food Analysis and Instrumentation. Theory and Practice. (Analytical Techniques) 2nd edition. Lagos: Napthali Prints.

[45] Ragaee, S, Abdel-Aal, E.M., \& Noaman, M. (2006). Antioxidant activity and nutrient composition of selected cereals for food use. Food chemistry, $98 \quad$ (1), 8.https://doi.org/10.1016/j.foodchem.2005.04.039

[46] Reddy, N. R., Pierson, M. D., Sathe, S. K., \& Salunkhe, D. K. (1982). Legume-based fermented foods: their preparation and nutritional quality. Critical Reviews in Food Science and Nutrition, 17(4), 335370.https://doi.org/10.1080/10408398209527353

[47] Scheffé, H. (1963). The simplex-centroid design for experiments with mixtures. Journal of the Royal Statistical Society, 25(2), 235251.https://doi.org/10.1111/j.2517-6161.1963.tb00506.x

[48] Sharma, J.L., \&Caralli, S. (2004). A Dictionary of Food and Nutrition. CBS Publishers. New Delhi. 1-12.

[49] Standing Committee on Nutrition (2004). Nutrition for improved development outcomes, 5th Report on the World Nutrition Situation Standing Committee on Nutrition (SCN) Geneva.

[50] Temple, V. J., \& Bassa, J. D. (1991). Proximate chemical composition of acha (Digitaria exilis) Grain. Journal of the Science of Food and Agriculture, 56(4), 561563.https://doi.org/10.1002/jsfa.2740560415

[51] Vining, G. G., Cornell, J. A., \& Myers, R. H. (1993). A graphical approach for evaluating mixture designs. Journal of the Royal Statistical Society. Series C, Applied Statistics, 42(1), 127.https://doi.org/10.2307/2347415 